\title{
Concommitant occurance of dens invaginatus and talon cusp: A case report
}

\section{Ocorrência simultânea de dens invaginatus e cúspide talon: relato de caso}

\begin{abstract}
Purpose: Morphological dental anomalies of the maxillary lateral incisors are relatively common. However, their simultaneous occurrence is a relatively rare event. We report a case of dens invaginatus and talon cusp concurrently affecting maxillary lateral incisors. The etiology, pathophysiology, association with other dental anomalies, as well as various treatment modalities of these anomalies are discussed.

Case description: An 18-year-old male patient reported with a complaint of crowding of maxillary front teeth. On intraoral examination, permanent dentition with Class I malocclusion with anterior crowding was observed. Tooth 12 showed a radiopaque invagination from a lingual pit but confined to the crown of the tooth. This invagination was approximately circular with a central core of radiolucency, which was consistent with the diagnosis of a dens invaginatus type I. Tooth 22 showed the talon cusp as a typical inverted cone with enamel and dentine layers and a pulp horn extending only into the base of the cusp. Talon cusp was treated by prophylactic enameloplasty to avoid plaque accumulation, the deep lingual pit was sealed using composite resin and regular clinical and radiographic follow-up was advised. Patient was scheduled for orthodontic treatment to correct crowding of maxillary anterior teeth.

Conclusion: We emphasize the fact that detailed clinical and radiographic examination of the maxillary lateral incisors is vital in avoiding complications.
\end{abstract}

Key words: Developmental anomalies; dens invaginatus; talon cusp

\section{Resumo}

Objetivo: Anomalias morfológicas dentárias dos incisivos laterais superiores são relativamente comuns. No entanto, a sua ocorrência simultânea é um evento relativamente raro. Relatamos um caso de dens invaginatus e cúspide talon simultaneamente afetando incisivos laterais superiores. A etiologia, fisiopatologia, associação com outras anomalias dentárias, bem como várias modalidades de tratamento destas anomalias são discutidas.

Descrição do caso: Um paciente de 18 anos, sexo masculino, relatou com queixa de apinhamento dos dentes anteriores superiores. Ao exame intraoral observou-se dentição permanente com má oclusão Classe I com apinhamento anterior. O dente 12 mostrou uma invaginação radiopaca lingual, confinada à coroa do dente. Esta invaginação era aproximadamente circular, com um núcleo central de radioluscência, que foi compatível com o diagnóstico de dens invaginatus tipo I. O dente 22 apresentou uma cúspide talon como um cone invertido típico com esmalte e dentina em camadas. A cúspide talon foi tratada por ameloplastia profilática para evitar acúmulo de placa, a fissura lingual foi selada com resina composta e foram aconselhados controles clínicos e radiográficos. $\bigcirc$ paciente foi encaminhado para tratamento ortodôntico para corrigir o apinhamento dos dentes anteriores superiores.

Conclusão: Enfatizamos o fato de que o exame clínico e radiográfico detalhado dos incisivos laterais superiores é vital para evitar complicações.

Palavras-chave: Anomalias do desenvolvimento; dens invaginatus; cúspide talon

\author{
Monica Yadav a \\ Meghana S.M b \\ Sandip R. Kulkarni a
}

a Department of Oral Pathology and Microbiology, Terna Dental College and Hospital, Nerul, Navi Mumbai, India

${ }^{b}$ Department of Oral Pathology, Terna Dental College and Hospital, Nerul, Navi Mumbai, India

\author{
Correspondence: \\ Monica Yadav \\ Department of Oral Pathology and Microbiology, \\ Terna Dental College and Hospital, \\ Sector no. 22,Nerul, Navi Mumbai-400706 \\ India \\ E-mail:drmonicay@yahoo.com
}

Received: February 14, 2011

Accepted: May 20, 2011

Conflict of Interest Statement: The authors state that there are no financial and personal conflicts of interest that could have inappropriately influenced their work.

Copyright: (C) 2011 Yadav et al.; licensee EDIPUCRS. This is an Open Access article distributed under the terms of the Creative Commons AttributionNoncommercial-No Derivative Works 3.0 Unported License. 


\section{Introduction}

Abnormalities affecting the teeth are commonly encountered in the dental office. They are best understood from the developmental point of view, since they occur during morphogenesis, hence described as developmental disturbances. Two such disturbances occurring in a rare combination are: dens invaginatus and talon's cusp. Dens invaginatus (dens in dente, dilated composite odontome, etc.) is a developmental anomaly resulting from an invagination in the surface of the crown or root before calcification has occurred (1). The invaginatus may vary from a slightly accentuated lingual pit to deep foldings reaching to the apical foramen (1). It can affect both primary and permanent teeth and its prevalence is reported to be $1.7 \%-10 \%(2)$. All the published studies found that maxillary lateral incisors were the most commonly affected teeth, followed in descending order by permanent central incisors, canines and molars $(1,2)$. On the other hand, talon's cusp, so named because it resembles an eagle's talon, is an uncommon anomaly that occurs as a nodule or tubercle. This cusp is composed of normal enamel, dentin and varying extension of pulp tissue. It occurs with a frequency of 0.04-1.05\% (3), with the maxillary lateral incisors showing the maximum predilection. Clinically it ranges from an enlarged cingulum to a large well-delineated cusp extending beyond the incisal edge of tooth. Based on the degree of their formation and extension, the anomaly can be classified as - talon, semitalon and trace talon. This was later modified as type 1: major talon, type 2: minor talon and type 3: trace talon. Majority of the cases reported in literature indicate talon's cusp as an isolated anomaly, however it may be associated with other somatic (Rubinstein-Taybi syndrome, incontinenti apigmentiachromians and Ellis-Van Creveld syndrome) and odontogenic abnormalities (4).

\section{Case Description}

An 18-year-old male patient reported with a complaint of crowding of maxillary anterior teeth. The patient appeared healthy and of normal physical development for his age. On intraoral examination, permanent dentition with Class I malocclusion with anterior crowding was observed. Interestingly, a deep pit was seen on the lingual surface of tooth 12 (Fig. 1) and an accessory cusp was seen on the lingual surface of tooth 22 (Fig. 2). These two developmental anomalies form the subject of our case report. The oral mucosa appeared normal with minimal inflammatory changes.

IOPA (intraoral) of tooth 12 showed a radiopaque invagination from a lingual pit but confined to the crown of the tooth. This invagination was approximately circular with a central core of radiolucency, which was consistent with the diagnosis of a dens invaginatus type I (Fig. 3). On the other hand IOPA (intraoral) of tooth 22 showed the talon cusp as a typical inverted cone with enamel and dentine layers and a pulp horn extending only into the base of the cusp (Fig. 4). Patient was clinically asymptomatic and neither of these anomalies was associated with caries or gingivitis and there was no evidence of loss of vitality of the lateral incisors. Talon's cusp was treated by prophylactic enameloplasty to avoid plaque accumulation, the deep lingual pit was sealed using composite resin and regular clinical and radiographic follow-up was advised. Patient was scheduled for orthodontic treatment to correct the crowding of maxillary anterior teeth.

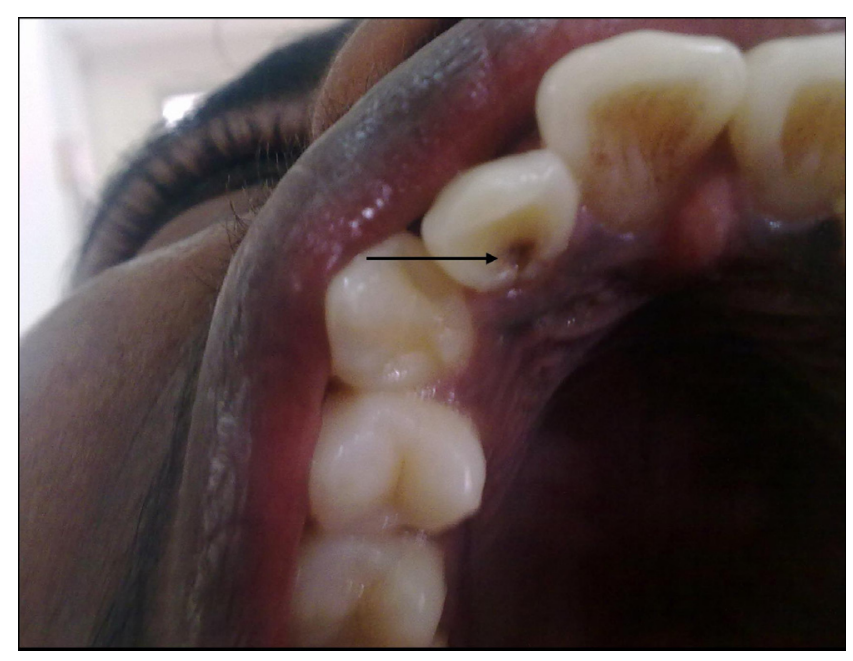

Fig. 1. Tooth 12 showing a deep pit on the lingual surface (arrow).

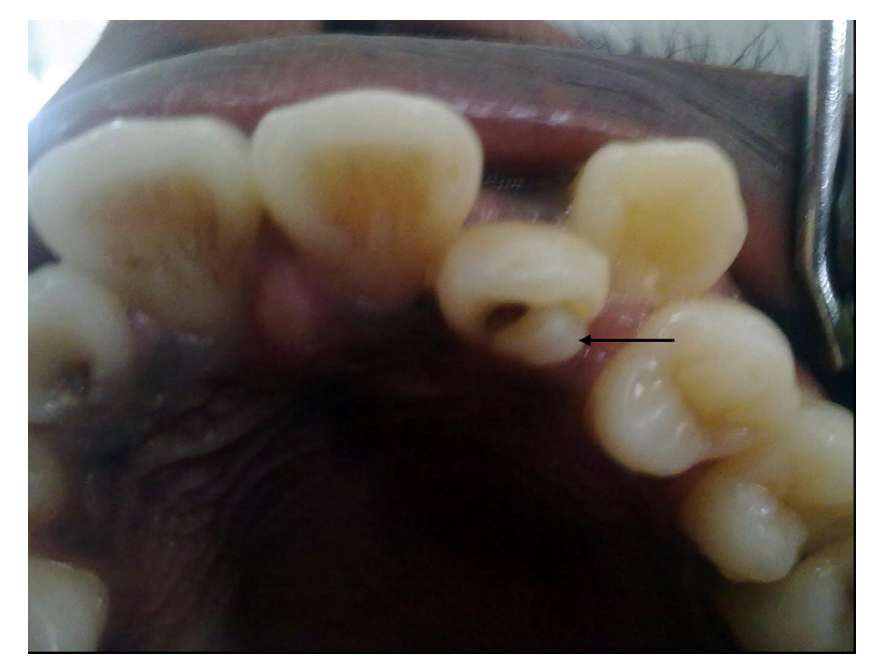

Fig. 2. Tooth 22 showing an accessory cusp on the lingual surface (arrow). 


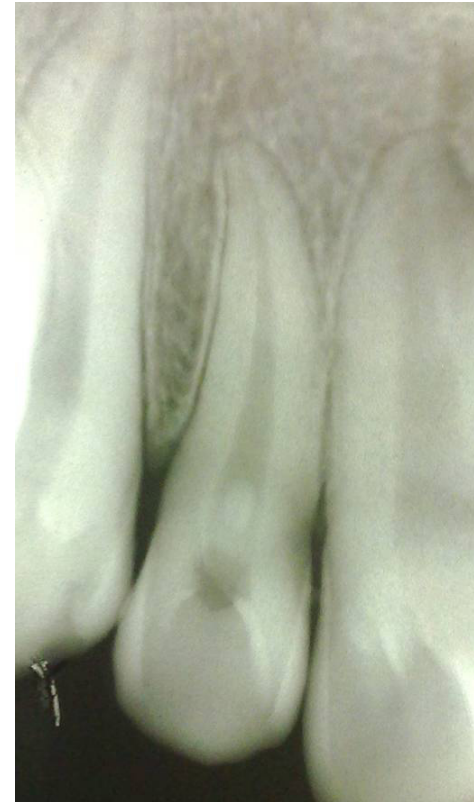

Fig. 3. IOPA of tooth showing a radiopaque invagination from a lingual pit.

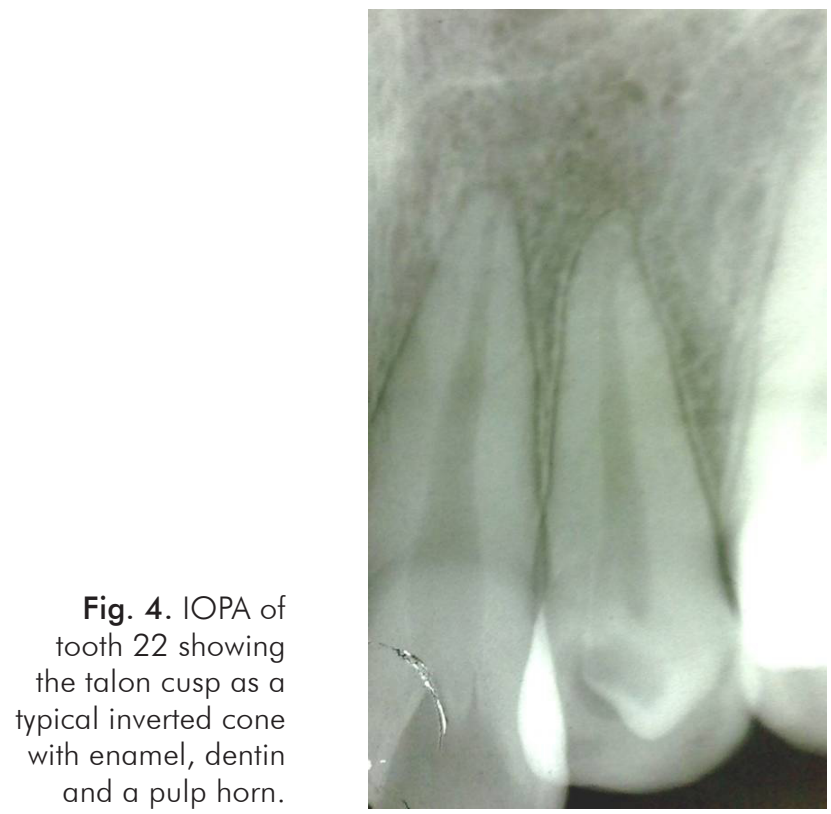

\section{Discussion}

Simultaneous occurrence of multiple dental abnormalities is relatively common. Anomalies of the talon's cusp, dens invaginatus, and palato-gingival groove predominantly affect the maxillary incisor region, which is also the most frequent site for supernumerary teeth. Individually, the developmental dental abnormalities affecting lateral incisors are well characterized but their cause(s) remain unknown $(5,6)$. It has been proposed that the relatively small lateral incisor tooth germ may be directly affected by forces generated by the tooth germs of the central incisor and canine, which develop seven months earlier. Localized pressure on a tooth germ during morpho-differentiation might cause buckling, with either outfolding or infolding of the dental lamina. However, it seems more likely that these malformations are genetically determined because they are highly reproducible in shape, show predilection for some racial groups and often occur together (7). Moyer's states that the most distal tooth within each group displays the greatest variability in size, shape and calcification timing (4). Studies have proved that the prevalance of talon's cusp varies considerably between ethnic groups, ranging from $0.06 \%$ in Mexican children to $7.7 \%$ in Indian children. The anomaly occurs with higher incidence in Mongoloid populations than Caucasians and Negroes (4). The genetic basis of tooth shape and size is being elucidated and is very complex but tightly controlled. It seems likely that these anomalies will turnout to be primarily under genetic control even though not strongly heritable (7). While these anomalies may sometimes compromise pulp vitality they are often asymptomatic incidental findings during routine clinical or radiographic examination, as in the current case. If this condition is not recognized early, premature tooth loss may result from communication with the pulp or predisposition to caries, resulting in pulp necrosis and periapical pathosis.

Similar associations with other anomalies have been reported occasionally: talon cusp with mesiodens (8), with odontomes (9), with dens invaginatus, with supernumerary teeth, with dens evaginatus of posterior teeth with palatal invagination (10), with shovel-shaped incisors, with congenitally missing teeth and large Carabelli's cusps (5). The presence of talon cusp and dens invaginatus in the same tooth, as here, appears quite rare, if reported. Mader (1981) and Acs, Pokala and Cozzi (1992) (11) have described concomitant talon cusp and supernumerary mesiodens. A possible association between dens invaginatus and Carabelli's cusps has also been reported previously (12).

Clinical management of these anomalies varies from case to case. Treatment of dens invaginatus ranges from conservative restoration of the opening to endodontic treatment or extraction (13). Talon cusp may cause occlusal interference and trap plaque, predisposing to caries, periodontitis and trauma to the tongue. Attrition may expose the central pulp horn, so that conservative management, reduction, coverage and endodontic treatment may all play a role (5). Also, gradual periodic reduction of the cusp with fluoride as a desensitizing agent along with regular clinical and radiographic follow up could be beneficial.

The most significant clinical concern of dens invaginatus is the risk of developing pulpal pathology. The invagination commonly communicates with the oral cavity, allowing the entry of irritants and microorganisms directly into the pulpal tissue. Sometimes fine canals extend between the invagination and the pulp chamber, resulting in pulpal and periapical pathology even in the absence of dental caries (14). Pulpal involvement can occur at a young age, when the root is immature and not completely formed. In these cases, the difficulty is to facilitate the apical closure before obturation. Other reported sequelae of undiagnosed and untreated invaginated teeth included eruption delay, cysts and internal resorption $(2,15)$. 


\section{Conclusions}

To summarize, due to the high incidence of developmental anomalies involving maxillary lateral incisors, these teeth should be thoroughly investigated to avoid the risk of developing pulpal and periapical pathologies. The developmental anomalies thus established should be strictly monitored from time to time.

References 1. Zengin AZ, Sumer AP, Celenk P. Double dens invaginatus: report of three cases. Eur J Dent 2009;3:67-70.

2. Galindo-Moreno PA, Parra-Vázquez MJ, Sánchez-Fernández E, Avila-Ortiz GA. Maxillary cyst associated with an invaginated tooth: a case report and literature review. Quintessence Int 2003;34:509-14.

3. Abbot PV. Labial and palatal "talon cusp" on the same tooth-a case report. Oral Surg Oral Med Oral Pathol Oral Radiol Endod 1998,85:726-30.

4. Tiku A, Nadkarni U M, Damle S G. Management of two unusual cases of dens invaginatus and talon cusp associated with other dental anomalies. J Indian Soc Ped Prev Dent $2004 ; 22: 128-33$.

5. Segura JJ, Jimenez-Rubio. A Talon cusp affecting permanent maxillary lateral incisors in 2 family members. Oral Surg Oral Med Oral Pathol Oral Radiol Endod 1999;88:90-2.

6. O'Sullivan EA. Multiple dental anomalies in a young patient: a case report. Int J Paediatr Dent 2000;10:63-6.

7. Lorena SC, Oliveira DT, Odell EW. Multiple dental anomalies in the maxillary incisor region. J Oral Sci 2003;45:47-50.

8. Davis PJ, Brook AH. The presentation of talon cusp: diagnosis, clinical features, associations and possible aetiology. Br Dent J 1985;160:84-8.

9. Natkin E, Pitts DL, Worthington P. A case of talon cusp associated with other odontogenic abnormalities. J Endod 1983;9:491-5.

10. Rusmah M R. Talon cusp in Malaysia. Aust Dent J 1991;36:1 1-4.

11. Acs G, Pokala P, Cozzi E Shovel incisors, three-rooted molars, talon cusp, and supernumerary tooth in one patient. Pediatr Dent 1992;14:263-4.

12. Lewis R, Mountford D, Collins V, Miller J . Palatal invaginations in incisors and the presence of cusps of Carabelli. J Pedod 1984;8:285-92.

13. Chaniotis AM, Tzanetakis GN, Kontakiotis EG, Tosios KI. Combined endodontic and surgical management of a mandibular lateral incisor with a rare type of dens invaginatus. J Endod 2008;34:1255-60.

14. White SC, Pharoah MJ. Dental anomalies. Oral radiology: Principles and interpretation. $5^{\text {th }}$ ed. New York: Mosby; 2004.

15. Mupparapu M, Singer SR. A review of dens invaginatus (dens in dente) in permanent and primary teeth: report of a case in a microdontic maxillary lateral incisor. Quintessence Int 2006;37:125-9. 